Article

\title{
Innovation Capabilities and the Performance of Start-Ups in Korea: The Role of Government Support Policies
}

\author{
Se-Kyoung Choi ${ }^{1}$, Sangyun Han $^{2}$ and Kyu-Tae Kwak ${ }^{3, *(D)}$ \\ 1 Division of Shared Growth Research, Korea Small Business Institute, Seoul 07074, Korea; \\ skc0531@hotmail.com \\ 2 Department of International Commerce, Daejeon University, Daejeon 34520, Korea; syhan@dju.ac.kr \\ 3 Department of Global Culture Industry, Soonchunhyang University, Asan 31538, Korea \\ * Correspondence: ktkwak@sch.ac.kr
}

Citation: Choi, S.-K.; Han, S.; Kwak, K.-T. Innovation Capabilities and the Performance of Start-Ups in Korea: The Role of Government Support Policies. Sustainability 2021, 13, 6009. https://doi.org/10.3390/su13116009

Academic Editor: Ladislav Mura

Received: 1 May 2021

Accepted: 24 May 2021

Published: 26 May 2021

Publisher's Note: MDPI stays neutral with regard to jurisdictional claims in published maps and institutional affiliations.

Copyright: (c) 2021 by the authors. Licensee MDPI, Basel, Switzerland. This article is an open access article distributed under the terms and conditions of the Creative Commons Attribution (CC BY) license (https:// creativecommons.org/licenses/by/ $4.0 /)$.

\begin{abstract}
What kind of capacity is needed to improve the performance of start-ups? How effective are government support policies in improving start-up performance? Start-ups are critical firm group for ensuring the prospective and sustainable growth of an economy, and thus many countries' governments have established support policies and they are likely to engage more widely in forwardlooking political support activities to ensure further growth and expansion. In this paper, the effect of innovation capabilities and government support policies on start-up performance is examined. We used an unbalanced panel data analysis with a random effect generalized least squares. We investigated the effect of government support policies on 4368 Korean start-ups. The findings indicated that technology and knowledge capabilities had positive effects on the sales performance of start-ups, and government financial support positively affected the relationship between knowledge capability and firm performance. However, when government financial support increased, marketing capability was negatively associated with firm performance. These results demonstrate the significant role of government financial support, including its crowding in but also its crowding out effect. Practical implications: To be more effective, governments should employ innovation-driven entrepreneurship policy approaches to support start-ups. To improve their performance, start-ups need to increase their technology and knowledge capabilities. This study extends recent efforts to understand more fully the effect of government support policies on start-ups differing in their technology, knowledge, and marketing capabilities.
\end{abstract}

Keywords: start-ups; government support policy; technology capability; knowledge capability; marketing capability

\section{Introduction}

Business creation is an important topic related to national economic policies. In particular, the fostering of start-ups has garnered considerable attention as a strategy to address the growing unemployment rate in advanced countries [1,2]. Generally, after an economic crisis in an emerging economy, the financial constraints will have a greater impact on small and medium enterprises (SMEs) than on large firms. The assumption that start-ups contribute positively to the growth of the national economy has been steadily emphasized by the Global Entrepreneurship Monitor (GEM), which surveys and publishes the entrepreneurial ecosystem in a national level. The level of dynamism of entrepreneurship is closely related to the level of development of the national economy. [3,4]. This GEM hypothesis is based on the view that start-ups not only increase dynamics of the market but also contribute to the growth of the economy, creating and forming new markets. Although the pull motivation of start-ups is extremely private factors, such as wanting to run one's own business, be recognized by others, etc. [5], the aggregate of these motivations could make the economies of many countries more innovative and dynamic. 
However, business creation alone is not sufficient to grow the national economy and increase employment. Most of the effects of business creation on national economic growth are related to 'innovation-driven entrepreneurship' rather than SME entrepreneurship [6]. Innovative start-ups have more probability of high growth, and the majority of new jobs are created by high-growth companies that are highly innovative [7-9]. Therefore, developed countries have focused either on promoting innovation-driven entrepreneurship or on policies to increase the growth potential of innovative start-ups. In addition, some innovative SMEs (small and medium-sized enterprises) in early stages are consciously addressing and taking the transition to sustainable model committed to SDGs (United Nations Sustainable Development Goals) [10]. Creating suitable conditions and a favourable business environment for start-ups is an essential factor in a vulnerable global market environment [11]. Thus, many countries are ramping up some government support-including financial, R\&D, etc.-for SMEs with the objective of mitigating social and economic polarization [12].

Since the mid-2000s, the Korean government's business creation policy has shifted from supporting SMEs to fostering start-ups with high growth potential, by focusing on stimulating innovative or technology-driven entrepreneurship. Despite this policy transition to innovation-driven entrepreneurship and various support measures, neither the level of job creation nor the effectiveness of government support have been positive in Korea. According to the 2016/2017 GEM (Global Entrepreneurship Monitor) report [13], comparing the employment rates of major countries in the world, Korea's total early-stage entrepreneurial activity rate was only $6.7 \%$ which was ranked 52nd out of 64 countries surveyed. Furthermore, the proportion of early-stage entrepreneurial activity of wholesale and retail businesses, which corresponds to 'necessity entrepreneurship', was 46.4\%. A previous study that analysed the effectiveness of the Korean government's support policies for start-ups reported the following: (1) the presence of similar or duplicate policies, (2) a lack of effective support by the certification system for innovative start-ups or SMEs, and (3) limited demonstrated effectiveness of the financial support for start-ups and business ventures in Korea [14].

What explains the poor performance of the Korean government's policy, despite its goal of driving national economic growth by fostering innovation-driven entrepreneurship and tech start-ups? The reason may be the absence of accurate policy targets for developing innovation-driven entrepreneurship. Alternatively, the policy's poor performance may reflect a lack of measures that conform to the characteristics of innovation-driven entrepreneurship.

Innovation provides competitive advantages in business such that innovation-driven entrepreneurship has a greater effect than SME entrepreneurship on the growth of national economies and job creation [15]. However, because innovation is closely related to creativity, knowledge, technology, and research and development (R\&D), it requires a considerable amount of physical or non-physical investment [16]. Moreover, while successful innovation leads to high performance, uncertainty about the potential for success can lead to market failure. Accordingly, if a government seeks to promote innovation-driven entrepreneurship, it should either select business sectors with a high likelihood of success or focus on providing support programmes that, by enhancing innovation capabilities, positively affect the performance of start-ups. Therefore, this study empirically investigated the innovation-related business types and capabilities affecting the financial performance of start-ups and whether government support improved the performance of those start-ups.

The organization of the paper is as follows. Following the introduction, Section 2 summarizes the results of past studies on start-up innovation capabilities and types of government support for start-ups. Then, Section 3 establishes research hypotheses based on the results of Section 2. After that, the research method is outlined in Section 4, and the analysis results are presented in Section 5. Finally, Section 6 summarizes the findings and discusses the implications. 


\section{Literature Review}

\subsection{Innovation Capabilities and Start-Ups}

In business administration, innovation capability has been emphasised as one of the core competencies required for firms to secure competitive advantages from the resourcebased or dynamic capabilities perspective. The definition of innovation varies according to different researchers [17]. In previous studies, innovation was defined as 'an activity that creates new value added throughout the value chain by creating a new type of product or service through the introduction and utilisation of new ideas or technologies'. Innovation capability can be classified into three types. First, it can refer to a technology capability, the use of which increases the economic value of a company's products and services [18,19], such as by improving the quality of a product or enabling higher levels of productivity and commercialisation. Second, innovation capability can consist of knowledge that positively influences a company's strategy or decision-making. It corresponds to a learning capability, i.e., the degree to which organisational members actively embrace new changes [19], or to an absorptive capacity, i.e., the ability of a company to acquire, understand, transform, and utilise knowledge $[20,21]$. Third, it may be a marketing capability that improves a company's sales performance. In this case, it refers to a marketing mix activity aimed either at securing resources, such as workforce and infrastructure that are necessary to enter domestic and foreign markets so that products and services can be sold, or at understanding customer needs to provide the best value [21,22]. In this context, global mindsets or a global market orientation aimed at entering global markets beyond the narrow domestic market are typical examples $[23,24]$.

However, few studies have examined how these innovation capabilities affect the performance of start-ups. Instead, they tend to focus on the main factors affecting the performance of start-ups by considering the personal competencies of the entrepreneur rather than the innovation capability of the start-up. For example, Bird [25] emphasised the entrepreneur's personal competency as a factor influencing the success of the start-up, based on a theory of entrepreneurial competency. Similarly, other factors identified in previous studies of start-up performance have included entrepreneurship [26], self-efficacy [27], capture planning, relationship or organisational competency [28], and technical competency [29].

The theory of entrepreneurship competency has contributed to defining the main characteristics of entrepreneurs that influence the transition from the pre-start-up stage to the successful start-up. However, the capabilities of organisational units that influence the growth of a start-up after the initial stage have not been well discussed [30]. For governments, interest in promoting innovation-driven entrepreneurship is derived from the possibility of a high rate of growth. Therefore, a prerequisite for these promotional efforts is to determine which innovation capability factors of start-ups truly contribute to their financial performance.

\subsection{Goals and Types of Entrepreneurial Support Policies}

The theoretical rationale for governments to support start-ups is based on the disadvantages described by resource-based and transaction cost theories. Start-ups have several structural disadvantages [31]. First, they face a greater investment risk in technology and innovation because of their small size, difficulties in raising funds due to their low recognition among trading partners or consumers, and their limitations when it comes to creating markets due to low sales volumes [32]. Government support can reduce these structural disadvantages and thereby increase market dynamics in addition to preventing market failure due to monopolies [33].

A government policy supporting entrepreneurship can target the difficulties faced by start-ups, mainly during their growth stage, and create the entrepreneurial ecosystems necessary to encourage start-ups. The OECD [34] categorises the stages of business development into seed start-up, early growth, and expansion phases. Most entrepreneurship support policies focus on the needs of companies at the seed and start-up stages, whereas 
the focus of those based on the entrepreneurship ecosystem is on building an environment that promotes entrepreneurship within the macroscopic aspect of national economic development. The entrepreneurship ecosystem concept was considered in the study of Isenberg [35], which presented a strategy for the development of a national economy. The emphasis was on innovation systems and cluster functions to promote entrepreneurship. Key elements in the entrepreneurship ecosystem include entrepreneurship culture, innovative policies and leadership, adequate funding access, high-quality human capital, venture-oriented markets and various support measures. In effect, support policies based on an entrepreneurship ecosystem are a required element for the development of startups. Such policies consist of measures targeting entrepreneurship education, business incubation, technological development, policy funding, overseas entry, and legal systems.

However, the entrepreneurship support policies themselves are classified not according to the policy instruments necessary for entrepreneurship but from the perspective of policy users. This is due to the varying policy effects from the perspective of those users, even if the instruments are similar. Storey [36] categorised the SME support policies of OECD member countries according to 'policy targets' and 'regions', depending on the needs addressed by those policies. Policy targets focus on minority groups, such as women, indigenous people, the disabled, young people, freelancers, and the self-employed, while regions are related to support for local SMEs. Therefore, government entrepreneurship support policies can also be tailored according to targets and beneficiaries.

Lastly, entrepreneurship support policies can be developed according to the method of delivering the respective measures to their targets, as in the classification of public policies. This often includes direct or indirect, package or linkage, selective and focused support [37]. This can be observed in the tendency to emphasise the linkage between the means of support, as in selective support and focused support, with a view to enhancing the effectiveness and efficiency of government policies.

A government's entrepreneurship support policy is likely to intervene in the relationship between the start-up's innovation capabilities and financial performance, as the former will vary depending on the means, targets, and methods of support from the government. Therefore, the aim of this study was to identify the role of government support policy as one of the factors influencing the relationship between start-up innovativeness and financial performance.

\section{Hypotheses Development}

\subsection{Innovation-Related Industry and Start-Up Performance}

Thus far, there are no clear proxy indicators allowing the academic classification of and distinction between innovation-driven entrepreneurship and SME entrepreneurship. However, considering that industries with a high R\&D intensity, i.e., industries in which $R \& D$ costs account for a high proportion of sales, are classified as high-tech industries, start-ups in these industries are more likely to be innovation-driven. In fact, the OECD [38] recognises high-tech, medium-high-tech, medium-low-tech, and low-tech industries based on the intensity of their R\&D.

Previous studies found a positive relationship between R\&D investment and business performance [39,40]. In particular, the higher the R\&D intensity in high-tech-based companies, the better the company performance [41,42]. Accordingly, start-ups in a high-tech industry that have a higher R\&D intensity are more likely to achieve a higher financial performance.

Hypothesis (H1). The performance of a start-up in a high-tech industry will be better than that of a start-up in a non-high-tech industry. 


\subsection{Innovation Capabilities and Start-Up Performance}

As discussed above, innovation capabilities can be classified according to technology, knowledge, and marketing capabilities [18-20]. The level of technology capability in a start-up can be assessed through government certification of company innovation. For example, the Korean Government's Certification of Venture Business programme certifies the innovative capabilities of venture companies with respect to their technological and R\&D activities and their growth potential. For SMEs, it offers the Certification of the InnoBiz programme, which certifies technological innovation capabilities. Therefore, start-ups with certifications can be assumed to have high innovation capabilities in terms of their technological and R\&D activities.

Previous studies have shown that companies with excellent technology capabilities and increased R\&D activities are more likely to achieve higher sales and will have a higher growth potential $[19,43]$. In fact, the positive effects of innovation capabilities on financial and employment performance in venture-certified companies and on Inno-Biz certified SMEs have been demonstrated [44]. Accordingly, we hypothesised that venture-certified companies and Inno-Biz certified SMEs are more likely to record sales increases.

Hypothesis (H2). The performance of a start-up with a higher technology capability will be better than that of a start-up with a comparatively low technology capability.

Companies need to acquire, understand, and utilise knowledge from internal and external sources to increase their innovation capabilities. It is therefore essential that start-ups acquire absorptive capacities, i.e., capabilities to acquire and utilise knowledge regarding commercialisation from external sources.

Absorption capacity has been measured in various forms, including through the accumulation of intellectual property rights, assessed based on the patents owned by the company $[20,21,45]$. In previous studies, the ownership of intellectual property rights, such as patents and utility model rights, was shown to have a positive effect on the sales and financial performance of SMEs [46]. Therefore, having a higher knowledge capability, reflected by the quantity of intellectual property rights, is likely to have a positive effect on the sales performance of a start-up.

Hypothesis (H3). The performance of a start-up with greater knowledge capability will be better than that of a start-up with a comparatively low level of knowledge capability.

Marketing capability is another one of the innovative capabilities identified in previous studies. In particular, the marketing capabilities of export-oriented companies can encourage exports. In international business administration, marketing capabilities are acquired through the efficient and effective acquisition and utilisation of resources related to exports [23]. Marketing capabilities in exports can be further expanded into global expansion and global customer orientation [24]. Global expansion refers to the need for building the local infrastructure needed to export products and services and to adapt to local environments. Customer orientation relates to the degree of customer satisfaction, i.e., how well a company understands its customers' needs and whether it is able to offer the best value. Increasing either the levels of exported products sold in the global market or global customer orientation improves marketing capability, leading to better management performance in business ventures or SMEs [47]. Therefore, this study hypothesised that the higher the marketing capability, the greater the positive effect on sales performance.

Hypothesis (H4). The performance of a start-up with a higher marketing capability will be better than that of a start-up with a comparatively low level of marketing capability. 


\subsection{Policy Support and Start-Up Performance}

As described in the previous section, governments implement support policies for start-ups to overcome market failures such as investment uncertainty, information asymmetry, and an inefficient allocation of the resources required for optimal performance [32,48].

Conversely, start-ups accept policy support to meet their needs. While government support policy has been shown to positively impact the financial performance of a startup [49], the degree of impact depends on the level of budgetary support.

Hypothesis (H5). The performance of a start-up with a high level of government support will be better than that of a start-up with a comparatively low level of government support.

\subsection{Moderating the Effects of Policy Support}

Previous studies evaluating the performance of support policies for SMEs, including start-ups, focused on verifying the effectiveness of those policies and identifying the direct role of the level of government support as a proxy indicator [50]. However, the degree of impact determined by the study can be expected to vary depending on the size and nature of the policy support fund or the research target [51,52]. In this study, the characteristics of innovation-related industries and the innovation capabilities of start-ups were considered in identifying companies eligible for policy support. There is continued debate over the replacement and complementary effects of government support [53]. Studies that considered company size found that, for SMEs such as start-ups, government support had a complementary effect [54].

Hypothesis (H6). Government support for start-ups have moderating effect on the performance in terms of firm's technology sophistication and innovation capabilities.

Ju, Kim, and Park [55] showed that the larger the R\&D intensity of the company, the greater its complementary effect on the company's R\&D output, especially for companies benefitting from government support policies, such as those directed at technological development projects in Korea. Therefore, we hypothesised that increased government support for start-ups would have a positive effect on the relationship between those with high-tech industry characteristics and their sales performance.

Hypothesis (H6a). Government support for start-ups is more strongly associated with firm performance for start-ups in the high-tech industry.

For individual start-ups, the effect of the level of government support on the relationship between innovation capabilities and performance can be explained as follows. First, at the stage of market entry, certified innovative companies with a certain degree of status are able to produce products that are superior in performance, quality, cost, etc. and therefore achieve greater success [20]. Previous studies [43,44] showed that certified companies are more competitive, with higher management performance than non-certified companies, such that government certification can be expected to improve a start-up's performance. Therefore, a higher degree of government support for start-ups should result in a better performance.

Hypothesis (H6b). Government support for a start-up is more strongly associated with performance when the technology capability of that start-up is higher.

With government support, the increasing absorptive capacity of start-ups can have a positive effect on performance, as suggested in the discussion on the effectiveness of governmental support on R\&D. Earlier studies of government performance in supporting SMEs, including start-ups, found that an improved performance relating to intellectual 
property, such as patents [56,57], can enhance a company's competitiveness and thereby its financial performance [58].

Hypothesis (H6c). Government support for start-ups is more strongly associated with firm performance for start-ups with a higher knowledge capability.

During the full-scale expansion and growth stage, start-ups face funding limitations in the mass production of products, the establishment of marketing channels, follow-up R\&D, etc. $[31,33,39]$. Consequently, at this stage, start-ups may use government support policy to amplify private investment and thus increase production capacity but also to develop new, competitive products for export. Accordingly, the degree of government support is likely to improve a company's financial performance further, by enhancing global capabilities to actively develop export marketing strategies.

Hypothesis (H6d). Government support for start-ups is more strongly associated with firm performance when the marketing capability of those start-ups is higher performance.

\section{Method}

\subsection{Data and Analytical Method}

This study was based on the assumption that the financial performance of innovationdriven entrepreneurship is better than that of SME entrepreneurship. Considering that industries with high R\&D intensity, i.e., industries in which R\&D expenses drive a high proportion of sales, are classified as high-tech industries, start-ups in these industries are more likely to be innovation-driven enterprises. In fact, the OECD [36] uses R\&D intensity to define four levels of technology for each industry: high-tech industries, medium-hightech industries, medium-low-tech industries, and low-tech industries.

In the present study, a comprehensive analysis of the innovative characteristics of start-ups and the effect of government support policy on their growth was conducted by comparing firms that received government support and those that did not. The companies included in the study were in the manufacturing industry. Information about beneficiary companies was obtained from the Korean SME Integrated Management System (SIMS). The data showed that during a 6-year period, from 2010 to 2015, 55,124 start-ups benefited from government support. Company data were integrated by reviewing the companies' registration and business registration numbers. This resulted in the exclusion of the following companies from the analysis: companies in which it was unclear if they received government support policy, companies that received government support $>7$ years ago, and large companies and associations. In addition, the data layouts of the SIMS and KED were compared, and only similar content was collected. Companies with insufficient or irregular information and abnormal values were also excluded. Through this process, the data for 95,424 start-ups (49,501 start-ups received double the level of support) were collected and further analysed. As a reference, 10,203 start-ups were identified based on the degree of annual government funding support. To investigate the effect of government support policy on start-ups, from this group, companies in business for $>7$ years or whose financial data had not been disclosed or had since closed were excluded. Thus, 4368 start-ups that had benefited from $\geq 2$ years of government support policy were analysed to determine the moderating effects of start-up capability and government policy.

A panel model analysis enables the study of changes in the characteristics inferred from the sample group in the time series. This model was adopted as the main method of hypothesis testing in this study, since the data demonstrated cross-sectional and time-series properties simultaneously. Woodridge and Hausman specification tests were sequentially performed to identify the panel model analysis method best suited to the data characteristics. A random effect GLS regression was then applied to determine the effects of the control and predictor variables. STATA version 14.2 was used to perform the analysis. 


\subsection{Variables and Measurement}

The dependent variable 'growth of sales' refers to the sales performance of start-ups and was measured as 'the sales growth rate after one year compared to the previous year'. The innovation characteristics of start-ups were classified into 'industry characteristics' and 'innovation capabilities' and used as the four predictor variables. 'Industry characteristics' refer to whether the start-up was in a high-tech industry and was processed as a dummy variable by confirming whether 'the relevant technology level of the start-up can be described as state-of-the-art or high-tech'. The remaining three predictor variables were obtained by separating the 'innovation capabilities' of start-ups into three sub-factors, 'technology capability', 'knowledge capability', and 'marketing capability'. Technology capability referred to the ability of a start-up to transform a given technology into a commercial product and was measured based on the Certification of Venture Business or Certification of the Inno-Biz by the Korean government. The technology capability as a dummy variable equals 1 if a firm have any certification and 0 otherwise. Knowledge capability was defined according to the competitive advantage it inferred and the ability of a firm to distinguish itself; it was measured based on the yearly number of possession of intellectual property rights such as patents. Marketing capability evaluated the global orientation of a start-up and was measured by the export performance (annual export value).

Lastly, the effect of government support policy was evaluated using 'government support' (annual level of government support fund) as a control variable to examine changes in the effect of the predictor variables on the dependent variable. In addition, both the unique characteristics of the start-up that affected its performance and situational variables, such as 'firm age', 'firm size (size of assets)', 'headquarters location (dummy, $1=$ metropolitan area, $0=$ non-metropolitan)', and 'year effect', were controlled. Table 1 lists the measurement information and the statistics applied to the variables used in the study.

Table 1. Descriptive statistics.

\begin{tabular}{|c|c|c|c|c|c|}
\hline Variable & Obs. & Mean & Std. Dev. & Min & Max \\
\hline Growth of sales (\%) & 29,630 & 13.82 & 64.88 & -0.99 & 994.80 \\
\hline Annual sales (KRW 1000) & 29,630 & $2,192,126$ & $4,708,782$ & 1 & $142,000,000$ \\
\hline $\begin{array}{c}\text { Industry characteristics } \\
\text { Dummy, High-tech industry }=1 \text { ) }\end{array}$ & 28,561 & 0.61 & 0.49 & 0 & 1 \\
\hline $\begin{array}{c}\text { Technology capability } \\
\text { Dummy, Certified company }=1 \text { ) }\end{array}$ & 29,630 & 0.33 & 0.47 & 0 & 1 \\
\hline $\begin{array}{l}\text { Knowledge capability } \\
\text { No. of Intellectual property) }\end{array}$ & 29,630 & 0.15 & 0.85 & 0 & 47 \\
\hline $\begin{array}{c}\text { Marketing capability } \\
\text { Annual export scale, } K R W \text { 1000) }\end{array}$ & 29,630 & 110,180 & $1,151,730$ & 0 & $70,246,550$ \\
\hline Marketing capability (log) & 29,630 & -5.54 & 3.79 & -6.91 & 11.16 \\
\hline $\begin{array}{l}\text { Government support } \\
\text { Amount of support fund, } K R W 1000)\end{array}$ & 29,630 & $228,933.30$ & $488,655.80$ & 0 & $16,900,000$ \\
\hline Government support $(\log )$ & 29,630 & 9.36 & 6.31 & -6.91 & 16.64 \\
\hline Firm age (year) & 28,828 & 5.83 & 3.29 & 0.65 & 49.25 \\
\hline Firm size (total assets, $K R W 1000$ ) & 25,120 & $2,025,957$ & $3,789,341$ & 3.21 & $104,000,000$ \\
\hline Firm size $(\log )$ & 25,120 & 13.45 & 1.67 & 1.17 & 18.46 \\
\hline $\begin{array}{c}\text { Headquarters location } \\
\text { Dummy, metropolitan area }=1 \text { ) }\end{array}$ & 21,027 & 0.4 & 0.19 & 0 & 1 \\
\hline
\end{tabular}




\section{Analysis Results}

An analysis of the correlations between the variables used in this study showed that there was no multicollinearity (Table 2).

Table 2. Correlations Matrix.

\begin{tabular}{|c|c|c|c|c|c|c|c|c|c|c|}
\hline Variable & VIF & 1 & 2 & 3 & 4 & 5 & 6 & 7 & 8 & 9 \\
\hline 1 Growth of sales & - & 1 & & & & & & & & \\
\hline 2 Firm age & 1.20 & $-0.05 *$ & 1 & & & & & & & \\
\hline 3 Firm size & 1.27 & -0.07 * & $0.12 *$ & 1 & & & & & & \\
\hline 4 Headquarters location & 1.01 & $0.08 *$ & $-0.07 *$ & $-0.13 *$ & 1 & & & & & \\
\hline 5 Industry characteristics & 1.05 & -0.00 & $0.02 *$ & $-0.06^{*}$ & $0.03 *$ & 1 & & & & \\
\hline 6 Technology capability & 1.13 & $0.04 *$ & $-0.05 *$ & $0.03 *$ & $0.10 *$ & $0.16^{*}$ & 1 & & & \\
\hline 7 Knowledge capability & 1.00 & $0.04 *$ & $-0.02 *$ & $-0.03 *$ & $0.10 *$ & 0.00 & $0.03 *$ & 1 & & \\
\hline 8 Marketing capability & 1.05 & -0.00 & 0.00 & $0.03 *$ & -0.00 & $0.04 *$ & $-0.00 *$ & -0.00 & 1 & \\
\hline 9 Government support & 1.51 & $0.07 *$ & $-0.04 *$ & -0.00 & $0.13 *$ & $-0.02 *$ & 0.07 * & $0.04^{*}$ & -0.00 & 1 \\
\hline
\end{tabular}

Note: ${ }^{*} p<0.05$ (two-tailed test).

Table 3 shows the start-ups' industry characteristics and innovation capabilities in terms of sales performance, and the moderating effect of government support. The results of the hypotheses test in terms of the impact on sales performance are also displayed. Model (2) in Table 3 relates to the effect of the start-ups' industry characteristics and innovation capabilities, as predictor variables, on sales performance. Model (3) is the result of adding government support as the moderating variable. Model (4) is the result of verifying the moderating effect of government support by including the interaction terms that combine the predictor and moderating variables. This is to confirm the moderating effect of government supports on the start-up's performance and various firm's attributes because the amount of government support for start-ups can be also differed by the characteristics of the industry, and type of support-enhancing technology, knowledge, and marketing capabilities.

Table 3. Result of panel GLS regression with random effect.

\begin{tabular}{|c|c|c|c|c|c|c|c|c|}
\hline \multirow{2}{*}{$\frac{\mathbf{D V}=\text { Growth of Sales }}{\text { Constant }}$} & \multicolumn{2}{|c|}{ Model (1) } & \multicolumn{2}{|c|}{ Model (2) } & \multicolumn{2}{|c|}{ Model (3) } & \multicolumn{2}{|c|}{ Model (4) } \\
\hline & $7.84^{* * *}$ & $(0.18)$ & $7.27^{* * *}$ & $(0.21)$ & $7.48^{* * *}$ & $(0.23)$ & $6.95^{* * *}$ & $(0.24)$ \\
\hline Firm age & $0.09^{* * *}$ & $(0.01)$ & $0.08^{* * *}$ & $(0.01)$ & $0.08^{* * *}$ & $(0.01)$ & $0.07^{* * *}$ & $(0.01)$ \\
\hline Firm size & $0.58^{* * *}$ & $(0.01)$ & $0.56^{* * *}$ & $(0.01)$ & $0.58^{* * *}$ & $(0.02)$ & $0.55^{* * *}$ & $(0.02)$ \\
\hline Headquarters location & $0.11^{* * *}$ & $(0.03)$ & $0.11^{* * *}$ & $(0.03)$ & $0.10^{* * *}$ & $(0.03)$ & $0.09^{* * *}$ & $(0.03)$ \\
\hline year_2010 & $-0.55^{* * *}$ & $(0.07)$ & $-0.58^{* * *}$ & $(0.07)$ & $-0.54 * * *$ & $(0.07)$ & $-0.46^{* * *}$ & $(0.07)$ \\
\hline year_2011 & $-0.78^{* * *}$ & $(0.06)$ & $-0.80^{* * *}$ & $(0.06)$ & $-0.77^{* * *}$ & $(0.06)$ & $-0.71^{* * *}$ & $(0.06)$ \\
\hline year_2012 & $-0.77^{* * *}$ & $(0.06)$ & $-0.79 * * *$ & $(0.06)$ & $-0.76^{* * *}$ & $(0.06)$ & $-0.70^{* * *}$ & $(0.06)$ \\
\hline year_2013 & $-0.49^{* * *}$ & $(0.05)$ & $-0.52 * * *$ & $(0.05)$ & $-0.50 * * *$ & $(0.05)$ & $-0.48^{* * *}$ & $(0.05)$ \\
\hline year_2014 & $-0.37^{* * *}$ & $(0.05)$ & $-0.40^{* * *}$ & $(0.05)$ & $-0.39 * * *$ & $(0.05)$ & $-0.36^{* * *}$ & $(0.05)$ \\
\hline Industry characteristics (H1) & & & $0.06^{* *}$ & $(0.03)$ & $0.07^{* *}$ & $(0.03)$ & $0.06^{*}$ & $(0.06)$ \\
\hline Technology capability (H2) & & & $0.16^{* *}$ & $(0.07)$ & $0.16^{* *}$ & $(0.07)$ & $0.34 * *$ & $(0.14)$ \\
\hline Knowledge capability (H3) & & & $0.09^{* * *}$ & $(0.03)$ & $0.09^{* * *}$ & $(0.03)$ & $0.22^{* * *}$ & $(0.04)$ \\
\hline Marketing capability (H4) & & & $-0.03^{* * *}$ & $(0.00)$ & $-0.03 * * *$ & $(0.00)$ & $-0.08^{* * *}$ & $(0.01)$ \\
\hline Government support (GS) (H5) & & & & & $0.03^{* * *}$ & $(0.00)$ & $0.03^{* * *}$ & $(0.01)$ \\
\hline $\mathrm{H} 1 \times \mathrm{GS}(\mathrm{H} 6-1)$ & & & & & & & 0.00 & $(0.01)$ \\
\hline $\mathrm{H} 2 \times \mathrm{GS}(\mathrm{H} 6-2)$ & & & & & & & 0.01 & $(0.01)$ \\
\hline $\mathrm{H} 3 \times \mathrm{GS}(\mathrm{H} 6-3)$ & & & & & & & $0.02^{* * *}$ & $(0.00)$ \\
\hline $\mathrm{H} 4 \times \mathrm{GS}(\mathrm{H} 6-4)$ & & & & & & & $-0.01^{* * *}$ & $(0.00)$ \\
\hline Observations & \multicolumn{2}{|c|}{18,352} & \multicolumn{2}{|c|}{18,352} & \multicolumn{2}{|c|}{18,352} & \multicolumn{2}{|c|}{18,352} \\
\hline Wald $\chi 2(d f)$ & \multicolumn{2}{|c|}{$3117.34^{* * *}(8)$} & \multicolumn{2}{|c|}{$3361.39^{* * *}(12)$} & \multicolumn{2}{|c|}{$3364.13^{* * *}(13)$} & \multicolumn{2}{|c|}{$3630.80 * * *(17)$} \\
\hline$R^{2}$ (Overall) & \multicolumn{2}{|c|}{0.1958} & \multicolumn{2}{|c|}{0.1992} & \multicolumn{2}{|c|}{0.1998} & \multicolumn{2}{|c|}{0.2053} \\
\hline
\end{tabular}

Note: Numbers in parentheses are robust standard errors. ${ }^{*} p<0.05,{ }^{* *} p<0.01,{ }^{* * *} p<0.001$ (using Wald test statistics, two-tailed test). 
The results of the analysis are as follows. First, the start-ups' industry characteristics (H1) were found to have a positive effect on sales performance $\left(\beta=0.06^{* *}, \mathrm{SE}=0.03\right)$. This was shown by the excellent sales performance of start-ups with state-of-the-art technology or a high level of technology.

In addition, both the technology capability $\left(\mathrm{H} 2, \beta=0.016^{* *}\right.$, SE $\left.=0.07\right)$ and the knowledge capability $\left(\mathrm{H} 3, \beta=0.09^{* * *}, \mathrm{SE}=0.03\right)$ of the start-up had a positive effect on sales performance. Thus, the efforts of individual start-ups to pursue innovation certification and to distinguish themselves, such as through patents, contributed positively to sales growth. However, marketing capability (H4) had a negative effect on the sales growth of start-ups $\left(\beta=-0.03^{* * *}, \mathrm{SE}=0.00\right)$, which indicated that the initial global market orientation of a start-up can negatively impact sales growth. This suggests that a longer period of time is required before the effect of export performance is reflected in sales performance.

As hypothesised (H5), government support was found to have a positive effect on the sales growth rate of start-ups $\left(\beta=0.03^{* * *}, \mathrm{SE}=0.00\right)$, and strengthened the relationship $\left(\mathrm{H} 6-3, \beta=-0.02^{* * *}, \mathrm{SE}=0.00\right)$ between their knowledge capability and sales growth. Government support also ameliorated $\left(\mathrm{H} 6-4, \beta=-0.01^{* * *}, \mathrm{SE}=0.00\right)$ the negative effect of the start-ups' marketing capability on sales growth. According to this result, the influence of government support on start-ups is particularly positive in the technology and export sectors. By contrast, there was no significant moderating effect of government support (H6-1, H6-2) on the relationship between industry characteristics and technology capability in terms of sales growth.

\section{Discussion and Conclusions}

Although the achievement of SDGs has become one of the most important goals across the global economy [11], the importance and effect of SMEs government support policy has been not fully investigated in this perspective. Therefore, this study examined the impact of innovation characteristics and government support on the financial performance of start-ups. The initial hypothesis was that government support has a positive effect on the impact of a start-up's innovation characteristics on sales growth. The results of the analysis were as follows. First, operating in a knowledge-based or high-tech industry had a positive effect on a start-up's sales performance. Thus, innovation-driven enterprises that are based on knowledge, technology, and skills are more likely to survive and will grow faster than SMEs. Among the innovation capabilities, the technology and knowledge capabilities of a start-up will have positive effects on its sales performance. In addition, sales growth is higher for start-ups with a higher level of technology capability in the market or that possess considerable intellectual property rights.

However, the marketing capability of a start-up was shown to have a negative effect on sales performance. In contrast to the results of previous studies [47,59], we found that an increase in annual exports did not drive a start-up's sales growth. This finding can be explained as follows. First, start-ups with stable sales in the domestic market may have more sales than export-oriented start-ups. In fact, the causal relationship between domestic sales and exports is unclear [60]. Second, start-ups face more challenges in entering overseas markets for exports [61].

In summary, our analysis of the moderating effect of government support showed that government support for start-ups had a positive effect on the influence of innovation characteristics on sales performance. In particular, government support was shown to double the improved effect on a start-up's sales performance conferred by a high level of intellectual property rights [33]. Our study also demonstrated that government support ameliorated the negative effect of annual exports on the sales performance of start-ups.

Our study has several academic and practical implications. First, it confirms the results of previous research [20,45], that the technology and knowledge innovation capabilities of a start-up positively contribute to its financial performance. High-tech start-ups categorised as innovation-driven or opportunity entrepreneurships can grow faster than the 
wholesale or retail trade or small-business start-ups categorised as necessity entrepreneurships. Therefore, to cultivate high-growth companies, the government should actively support innovation-driven start-ups that are leaders in high-tech industries and whose knowledge-based capital and technological levels are high. These results argue the boundary of government policy for start-ups and specify the support type, so it contributes to help government reconstructing their start-ups support program and policy directions.

Second, the ability of start-ups to secure stable sales in the domestic market is more important to the growth of the company than entering overseas markets. The need for 'born-global' start-ups is often emphasised, but annual exports may limit sales performance. This can be attributed to the nature of marketing capability, which differs from the startup's primary innovation (knowledge and technology) capabilities. Successful marketing capability is challenging unless the company is already at the mature stage of its business model, with marketing-related innovations aimed at entry into global markets. Therefore, it may be more rewarding for start-ups to enter the global market only after securing stable sales in the domestic market. This can help start-ups to make some management decisions more strategically and effectively in the globalization era.

Third, for start-ups with innovation capabilities such as knowledge and technology, government support can contribute to stable growth, despite several studies in which the policy effect of government support for start-ups was criticised [62]. However, this study demonstrated that for start-ups in knowledge-based and high-tech industries-and thus, with a high potential for innovation-driven entrepreneurship, as well as for start-ups with innovation capabilities-government support policies as a key instrument to increase both their survival and their potential transformation into high-growth companies. In this perspective, this study contributes to provide some solid verification why governments should intensively support the start-ups with innovation capabilities.

Despite these strengths of our study, we have four limitations. Firstly, we used several proxy indicators for innovation capabilities in the empirical analysis. Inherent innovation capabilities may differ from those that are acquired through activities. Nonetheless, for the purpose of conducting a quantitative analysis, innovation capabilities were measured based on the acquisition of certifications, the possession of intellectual property rights, the number of exports, etc. Therefore, in future studies, it will be essential to develop a method of measuring innovation capabilities by distinguishing between inherent capabilities and capabilities acquired through activities. Secondly, the performance of a start-up is measured by sales growth as a single variable. We considered that sales growth is the most relevant for start-ups in emerging economies because of attracting investment [63]. Nevertheless, in future studies, a firm's performance needs to be measured in various proxies such as profit growth, net income, market share, or employment growth. Thirdly, future studies should consider the various types of government support other than financial support, and come up with a measure to select targets for government support and the effect of that support. Government support for start-ups can increase the innovation capabilities of those companies and thus contribute to sales performance. However, start-ups that already enjoy a high sales performance may also be recipients of government support. Therefore, better qualitative results of future studies might be obtained by also analysing the selection process for government support. Lastly, considering the value of R-squared, our empirical model has a limitation that can only explain the impact of independent variables on the dependent variable - sales growth-at $20 \%$, at the most. We can infer that either the relationship between the dependent variable and other variables is non-linear or there are other variables that influence the value of the dependent variable. Thus, our findings suggest the need for future research to develop a more specific empirical model considering the complex relationship between the variables.

Author Contributions: Conceptualization, S.-K.C. and K.-T.K.; Data curation, S.-K.C.; Formal analysis, S.H.; Funding acquisition, K.-T.K.; Methodology, K.-T.K.; Writing-original draft, S.-K.C., S.H. and K.-T.K. All authors have read and agreed to the published version of the manuscript. 
Funding: This work was supported by the Soonchunhyang University Research Fund.

Institutional Review Board Statement: Not applicable.

Informed Consent Statement: Not applicable.

Data Availability Statement: Not available.

Conflicts of Interest: The authors declare no conflict of interest.

\section{References}

1. Ferreira, J.J.; Fayolle, A.; Fernandes, C.; Raposo, M. Effects of Schumpeterian and Kirznerian entrepreneurship on economic growth: Panel data evidence. Entrep. Reg. Dev. 2017, 29, 27-50. [CrossRef]

2. Hathaway, I.; Bell-Masterson, J.; Stangler, D. The Return of Business Creation. 2013. Available online: https:/ /www.kauffman. org/wp-content/uploads/2019/12/firmformationandeconomicgrowthjuly2013.pdf (accessed on 5 November 2020).

3. Levie, J.; Autio, E. A theoretical grounding and test of the GEM model. Small Bus. Econ. 2008, 31, 235-263. [CrossRef]

4. Dhahri, S.; Omri, A. Entrepreneurship contribution to the three pillars of sustainable development: What does the evidence really say? World Dev. 2018, 106, 64-77. [CrossRef]

5. Gódány, Z.; Machová, R.; Mura, L.; Zsigmond, T. Entrepreneurship Motivation in the 21st Century in Terms of Pull and Push Factors. TEM J. 2021, 10, 334-342. [CrossRef]

6. Aulet, W.; Murray, F.E. A Tale of Two Entrepreneurs: Understanding Differences in the Types of Entrepreneurship in the Economy. 2013. Available online: https:/ / papers.ssrn.com/sol3/papers.cfm?abstract_id=2259740 (accessed on 5 November 2020).

7. Bravo-Biosca, A.; Westlake, S. The Vital 6 per Cent: How High-Growth Innovative Businesses Generate Prosperity and Jobs. NESTA: London, 2009. Available online: https://media.nesta.org.uk/documents/vital-six-per-cent.pdf (accessed on 5 November 2020).

8. Eberhart, R.N.; Eesley, C.E.; Eisenhardt, K.M. FailureIsan Option: Institutional Change, Entrepreneurial Risk, and New Firm Growth. Organ. Sci. 2017, 28, 93-112. [CrossRef]

9. Stangler, D. High-Growth Firms and the Future of the American Economy. SSRN Electronic Journal. 2010. Available online: https: / files.eric.ed.gov / fulltext/ED515554.pdf (accessed on 5 November 2020).

10. Rubio-Mozos, E.; García-Muiña, F.E.; Fuentes-Moraleda, L. Rethinking 21st-Century Businesses: An Approach to Fourth Sector SMEs in Their Transition to a Sustainable Model Committed to SDGs. Sustainability 2019, 11, 5569. [CrossRef]

11. Fil'a, M.; Levicky, M.; Mura, L.; Maros, M.; Korenkova, M. Innovations for Business Management: Motivation and Barriers. Mark. Manag. Innov. 2020, 4, 266-278. [CrossRef]

12. Ilyas, S.; Hu, Z.; Wiwattanakornwong, K. Unleashing the role of top management and government support in green supply chain management and sustainable development goals. Environ. Sci. Pollut. Res. 2020, 27, 8210-8223. [CrossRef]

13. Global Entrepreneurship Monitor. 2016/2017 Global Report, GERA. 2017. Available online: https://www.c4e.org.cy/reports/20 17/gem-2016-2017-global-report-web-version-1486181226.pdf (accessed on 5 November 2020).

14. Han, S.; Kwon, S.; Yoo, J. A study on Improvement of Government Support Policies of Innovative SMEs. National Assembly Budget Office: Korea, 2015. Available online: https:/ / www.nabo.go.kr/Sub/01Report/05 (accessed on 5 November 2020).

15. OECD. New Sources of Growth: Knowledge-Based Capital-Key Analyses and Policy Conclusions; Synthesis Report; OECD Publishing: Paris, France, 2013. Available online: https://www.oecd-ilibrary.org/science-and-technology/oslo-manual_9789264013100-en (accessed on 5 November 2020).

16. OECD. Supporting Investment in Knowledge Capital, Growth and Innovation (Summary in Korean); OECD: Paris, France, 2013. [CrossRef]

17. Chen, M.-H.; Yang, Y. Typology and performance of new ventures in Taiwan. Int. J. Entrep. Behav. Res. 2009, 15, 398-414. [CrossRef]

18. Zawislak, P.; Alves, A.C.; Tello-Gamarra, J.; Barbieux, D.; Reichert, F.M. Innovation Capability: From Technology Development to Transaction Capability. J. Technol. Manag. Innov. 2012, 7, 14-27. [CrossRef]

19. Yam, R.C.; Lo, W.; Tang, E.P.; Lau, A.K. Analysis of sources of innovation, technological innovation capabilities, and performance: An empirical study of Hong Kong manufacturing industries. Res. Policy 2011, 40, 391-402. [CrossRef]

20. Patterson, W.; Ambrosini, V. Configuring absorptive capacity as a key process for research intensive firms. Technovation 2015, 36, 77-89. [CrossRef]

21. Santoro, G.; Bresciani, S.; Papa, A. Collaborative modes with Cultural and Creative Industries and innovation performance: The moderating role of heterogeneous sources of knowledge and absorptive capacity. Technovation 2020, 92, 102040. [CrossRef]

22. Vorhies, D.W.; Morgan, N.A. Benchmarking Marketing Capabilities for Sustainable Competitive Advantage. J. Mark. 2005, 69, 80-94. [CrossRef]

23. Kim, S.-D.; Jeon, I.-O. Effects of Global Capabilities of Small and Medium Businesses on Their Competitive Advantage and Business Management Performances. Int. J. Fuzzy Log. Intell. Syst. 2017, 16, 52-58. [CrossRef]

24. Küster, I.; Vila, N. The market orientation-innovation-success relationship: The role of internationalization strategy. Innov. Organ. Manag. 2011, 13, 36-54. [CrossRef] 
25. Bird, B. Toward a theory of entrepreneurial competency. In Advances in Entrepreneurship Firm Emergence and Growth; Katz, J.A., Brockhaus, R.H., Sr., Eds.; JAI Press: Greenwich, CT, USA, 1995; pp. 51-72. ISBN 9781559387132.

26. Bygrave, W.D. The Entrepreneurial Process. In The Portable MBA in Entrepreneurship; Bygrave, W., Zacharakis, A., Eds.; John Wiley \& Sons Inc.: Hoboken, NJ, USA, 2011; pp. 1-26. [CrossRef]

27. Hopp, C.; Stephan, U. The influence of socio-cultural environments on the performance of nascent entrepreneurs: Community culture, motivation, self-efficacy and start-up success. Entrep. Reg. Dev. 2012, 24, 917-945. [CrossRef]

28. Ahmad, N.H.; Ramayah, T.; Wilson, C.; Kummerow, L. Is entrepreneurial competency and business success relationship contingent upon business environment? Int. J. Entrep. Behav. Res. 2010, 16, 182-203. [CrossRef]

29. Mitchelmore, S.; Rowley, J. Entrepreneurial competencies: A literature review and development agenda. Int. J. Entrep. Behav. Res. 2010, 16, 92-111. [CrossRef]

30. Forbes, D.P.; Borchert, P.S.; Zellmer-Bruhn, M.E.; Sapienza, H.J. Entrepreneurial Team Formation: An Exploration of New Member Addition. Entrep. Theory Pract. 2006, 30, 225-248. [CrossRef]

31. Stoke, D.; Wilson, N. Small Business Management and Entrepreneurship, 6th ed.; South-Western Cengage Learning: London, UK, 2010. Available online: https:/ / trove.nla.gov.au/version/49309552 (accessed on 5 November 2020).

32. Schiffer, M.; Weder, B. Firm Size and the Business Environment: Worldwide Survey Results; World Bank Publications: Washington, DC, USA, 2001.

33. Watson, K.; Hogarth-Scott, S.; Wilson, N. Small business start-ups: Success factors and support implications. Int. J. Entrep. Behav. Res. 1998, 4, 217-238. [CrossRef]

34. OECD. The SME Financing Gap: Theory and Evidence. Available online: https://www.oecd-ilibrary.org/finance-andinvestment/the-sme-financing-gap-theory-and-evidence_fmt-v2006-art11-en (accessed on 5 November 2020).

35. Isenberg, D. The Entrepreneurship Ecosystem Strategy as a New Paradigm for Economic Policy: Principles for Cultivating EntrepreNeurship; Babson Entrepreneurship Ecosystem Project, Babson College: Babson Park, MA, USA, 2011; Available online: http:/ / www.innovationamerica.us/images/stories/2011/The-entrepreneurship-ecosystem-strategy-for-economic-growthpolicy-20110620183915.pdf (accessed on 5 November 2020).

36. Storey, D.J. Entrepreneurship, Small and Medium Sized Enterprises and Public Policies. In Handbook of Entrepreneurship Research; Springer Science and Business Media LLC: Boston, MA, USA, 2005; Volume 1, pp. 473-511.

37. Edler, J.; Shapira, P.; Cunningham, P.; Gök, A. Handbook of Innovation Policy Impact; Edward Elgar Publishing: Cheltenham, UK; Northampton, MA, USA, 2016.

38. OECD. ISIC REV.3 Technology Intensity Definition. 2011. Available online: https://www.oecd.org/sti/ind/48350231.pdf (accessed on 5 November 2020).

39. Zhu, Z.; Huang, F. The Effect of R\&D Investment on Firms' Financial Performance: Evidence from the Chinese Listed IT Firms. Mod. Econ. 2012, 3, 915-919. [CrossRef]

40. Tubbs, M. The Relationship Between R\&D and Company Performance. Res. Manag. 2007, 50, 23-30. [CrossRef]

41. Coad, A.; Rao, R. Firm growth and R\&D expenditure. Econ. Innov. New Technol. 2010, 19, 127-145. [CrossRef]

42. García-Manjón, J.V.; Romero-Merino, M.E. Research, development, and firm growth. Empirical evidence from European top R\&D spending firms. Res. Policy 2012, 41, 1084-1092. [CrossRef]

43. Yang, J. Innovation capability and corporate growth: An empirical investigation in China. J. Eng. Technol. Manag. 2012, 29, 34-46. [CrossRef]

44. Yoo, K.S.; Kim, Y.D. A Study on the Effects of Entrepreneurship and Innovation Activities of Venture Enterprises on the Increase Firms' Revenue. J. Korea Converg. Soc. 2017, 8, 329-341. (In Korean)

45. Lin, C.; Wu, Y.-J.; Chang, C.; Wang, W.; Lee, C.-Y. The alliance innovation performance of R\&D alliances-the absorptive capacity perspective. Technovation 2012, 32, 282-292. [CrossRef]

46. Agostini, L.; Nosella, A.; Filippini, R. Does intellectual capital allow improving innovation performance? A quantitative analysis in the SME context. J. Intellect. Cap. 2017, 18, 400-418. [CrossRef]

47. Cerrato, D.; Piva, M. The Effect of Global Orientation on the Performance of International New Ventures: Evidence from Italy. Manag. Int. Rev. 2015, 55, 857-883. [CrossRef]

48. Pergelova, A.; Angulo-Ruiz, F. The impact of government financial support on the performance of new firms: The role of competitive advantage as an intermediate outcome. Entrep. Reg. Dev. 2014, 26, 663-705. [CrossRef]

49. Ayoub, M.R.; Gottschalk, S.; Müller, B. Impact of public seed-funding on academic spin-offs. J. Technol. Transf. 2016, 42, 1100-1124. [CrossRef]

50. Link, A.N.; Scott, J.T. Public R\&D subsidies, outside private support, and employment growth. Econ. Innov. Neww Technol. 2013, 22, 537-550. [CrossRef]

51. Schneider, C.; Veugelers, R. On young highly innovative companies: Why they matter and how (not) to policy support them. Ind. Corp. Chang. 2010, 19, 969-1007. [CrossRef]

52. Serrasqueiro, Z.; Nunes, P.M.; Leitao, J. Sources of finance for R\&D investment: Empirical evidence from Portuguese SMEs using dynamic estimators. Innovation 2011, 13, 187-206. [CrossRef]

53. Lee, C.-Y. The differential effects of public R\&D support on firm R\&D: Theory and evidence from multi-country data. Technovation 2011, 31, 256-269. [CrossRef] 
54. Huergo, E.; Moreno, L. Subsidies or loans? Evaluating the impact of R\&D support programmes. Res. Policy 2017, 46, 1198-1214. [CrossRef]

55. Ju, H.S.; Kim, J.S.; Park, J.G. Analysis of the Effects of Public R\&D Subsidy on Private R\&D Investment in the Cleaner Pro-ductionComplementary or Crowding-out Effect. Clean Technol. 2011, 17, 181-188. (In Korean)

56. Almus, M.; Czarnitzki, D. The effects of public R\&D subsidies on firms' innovation activities: The case of Eastern Germany. J. Bus. Econ. Stat. 2003, 21, 226-236.

57. Uzuegbunam, I.; Liao, Y.-C.; Pittaway, L.; Jolley, G.J. Human capital, intellectual capital, and government venture capital. J. Entrep. Public Policy 2017, 6, 359-374. [CrossRef]

58. Hall, B.; Van Reenen, J. How effective are fiscal incentives for R\&D? A review of the evidence. Res. Policy 2000, 29, 449-469. [CrossRef]

59. Muller, P.; Mattes, A.; Lonkeu, O.-K.; Brown, J.; Farrenkopf, J.; Makowska, A.; Robin, N. Annual Report on European Smes 2017/2018: Special Background Document on the Internationalisation of Smes, Europe Union. 2018. Available online: https: / / op.europa.eu/en/publication-detail/- / publication/a435b6ed-e888-11e8-b690-01aa75ed71a1 (accessed on 5 November 2020).

60. Salomon, R.; Shaver, J.M. Export and domestic sales: Their interrelationship and determinants. Strat. Manag. J. 2005, 26, 855-871. [CrossRef]

61. Zucchella, A.; Brugnoli, A.; Bianco, A.D.; Bianco, A. Barriers to the Internationalization of SMEs: An Analysis from the Perspective of Support Service Providers. In Resources, Efficiency and Globalization; Palgrave Macmillan: London, UK, $2010 ;$ pp. 310-326.

62. Ribeiro-Soriano, D.; Galindo-Martín, M.-A. Government policies to support entrepreneurship. Entrep. Reg. Dev. 2012, 24, 861-864. [CrossRef]

63. Honjo, Y. Do profitable start-up firms grow faster? Evidence from Colombia. Cuad. Econ. 2018, 37, 727-754. [CrossRef] 